\title{
EVALUATION OF CAST METALLIC POSTS REPRODUCTION ACCORDING TO ITS QUANTITY AND POSITION INSIDE THE CASTING RING
}

\author{
AVALIAÇÃO DA REPRODUTIBILIDADE DOS NÚCLEOS METÁLICOS FUNDIDOS \\ EM FUNÇÃO DA QUANTIDADE E POSICIONAMENTO DOS PADRÕES \\ DE RESINA NO ANEL DE FUNDIÇÃO
}

Luciana de Rezende PINTO1, Gerson BONFANTE², José Fernando Scarelli LOPES ${ }^{3}$

1- DDS, MSc, Graduate student (Máster degree), Department of Prosthodontics, Hospital de Reabilitação de Anomalias Craniofaciais, University of São Paulo (HRAC-USP),Bauru, São Paulo, Brazil.

2- DDS, PhD, Associate Professor, Department of Prosthodontics, Bauru School of Dentistry, University of São Paulo, Bauru, São Paulo, Brazil.

3- DDS, MSc, Assistent Professor, Department of Prosthodontics, Hospital de Reabilitação de Anomalias Craniofaciais, University of São Paulo (HRAC-USP), Bauru, São Paulo, Brazil.

Corresponding address: Luciana de Rezende Pinto - Rua José Ferreira Marques, 10-41, apto.710 - Vila Cidade Universitária - Cep.: 17011-570 Bauru - SP - Telefone: (14) 3227-3279 - E-mail: lucianaderezende@yahoo.com.br

Received: May 31, 2004 - Modification: September 14, 2004 - Accepted: January 5, 2005

\begin{abstract}
T

1 he aim of this study was the evaluation about the influence of the quantity and the localization of resin patterns to cast metallic posts in its diameter and length reproduction. Seventy-two patterns for posts were fabricated by using prefabricated FKG plastic posts and divided for casting in 3 groups: G1-small ring/4 patterns, G2- medium ring/6 patterns, G3- big ring/8 patterns. Half of the patterns of each group were placed on the right side of the ring midline and the other half, on the left side, in order to guide the ring inside of the centrifuge. Using the comparative microscope, measures of diameter and length in different places were obtained before and after casting. The results were submitted to statistic analysis (ANOVA two way and Tukey's test), to make possible these observations: $1^{\circ}$ ) the position of patterns didn't influenced the measured dimensions. $2^{\circ}$ ) the same happened with the quantity of patterns inside the ring. $3^{\circ}$ ) only the pins of group G3 have presented statistically significant diameter differences. In conclusion, $1^{\circ}$ ) the position of patterns inside the ring and its quantity did not result in significant changes in pins length and diameter. $2^{\circ}$ ) Although there were no significant length alterations, significant ones were observed in the diameters 3, 6, and 9mm of Group G3.

Uniterms: Dental pins; Dental casting technique; Dental alloys.
\end{abstract}

\footnotetext{
RESUMO

Q

objetivo deste trabalho foi avaliar a influência do número e localização de padrões de resina para fundição de núcleos metálicos fundidos (NMF), na reprodução do diâmetro e comprimento dos pinos. Foram confeccionados 72 padrões de resina utilizando pinos plásticos pré-fabricados e divididos para fundição em 3 grupos: G1- anel pequeno/4padrões, G2- anel médio/ 6 padrões e G3-anel grande/8 padrões. Metade deles foi posicionada à direita da linha média do anel e metade à esquerda, servindo de orientação para posicionar o anel na centrífuga. Através do microscópio comparador foram obtidas medidas antes e depois da fundição, tanto do comprimento quanto do diâmetro em diferentes locais. Os resultados foram submetidos à análise estatística (ANOVA a dois critérios e Tukey), possibilitando as seguintes observações: $1^{\circ}$ ) a posição dos padrões não exerceu influência nas dimensões mensuradas. $2^{\circ}$ ) o mesmo ocorreu com a quantidade de padrões dentro do anel. $3^{\circ}$ ) apenas em relação ao diâmetro (3 e $6 \mathrm{~mm}$ ) dos pinos do grupo G3, houve diferença estatisticamente significante. Conclui-se que: $1^{\circ}$ ) a posição do padrão dentro do anel e o número de padrões não resultou em alteração significativa do comprimento e diâmetro dos pinos. $2^{\circ}$ ) A variação de diâmetro (3, 6, e 9mm) foi significante apenas para os pinos do grupo G3.

Unitermos: Pinos dentários; Técnica de fundição odontológica; Ligas dentárias.
} 


\section{INTRODUCTION}

The evolution of endodontic therapy allowed safer restoration of endodontically treated teeth. However, care should be taken when considering the remaining tooth structure, especially after the finding that cast metallic posts (CMP) do not provide reinforcement, but only forms of retention and resistance to the crown (Sorensen and Martinoff ${ }^{1^{0}}$ 1984).

Several factors may alter the dimensions of cast posts during their fabrication, such as the material and technique employed for fabrication, thickness of the investment layer, number and location of the patterns inside the ring, sprue size, type of alloy employed, oven temperature, pressure with which the alloy is injected inside the ring, number of cycles of the centrifuge and air escape. One of the most frequent alterations is the modification in the post length, which leads to formation of empty gaps between the post and the filling material inside the root canal, as reported in the studies of Phillips ${ }^{6}$ (1947) and Scaranelo, et al. ${ }^{8}$ (1990).

In a radiographic analysis of 344 abutment teeth of fixed prostheses, being 78\% with a CMP, Rocha, et al. ${ }^{7}$ (1997) observed that $94.46 \%$ had insufficient length, and a radiolucent area between the remaining filling material and the tip of the cast post was found in $55.71 \%$ of the posts analyzed, revealing failures in the clinical and/or laboratory steps. Bonfante, et al. ${ }^{1}$ (2000) conducted a radiographic evaluation of 1,000 single root posts and found a gap between the post and the filling material in $70 \%$ of the cases.

This empty gap leads to reduction of the post length and clinical drawbacks responsible for their failure, such as displacement because of lack of retention, root fracture due to the levering effect, and contamination of the cement by saliva (Morgano, Milot $^{3}$ 1993).

The literature is relatively scarce as to the possible sequels of this empty gap and its potential bacterial proliferation due to contamination during fabrication of the posts and then through the lateral canals, what leads to the development of periapical lesions. However, Zuolo, et al. ${ }^{12}$ (1996) and Valera, $\mathrm{Cia}^{11}$ (2000) demonstrated that the contact of the remaining root canal fillings with saliva during preparation of the root canals led to a significant increase in leakage.

Silva $^{9}$ (1999) has analyzed 50 posts and did not observe statistically significant differences between the length of the prepared root canal and the length of the post achieved with acrylic resin, demonstrating that the dimensional change occurred during casting. Moreover, radiographic analysis revealed a gradual increase in the empty gap after placement of the posts, indicating a shorter post after casting and some misfit when 3 patterns are cast inside the ring. The minimum variability of the measurement of the empty gap radiographically analyzed was $0.17 \mathrm{~mm}$ for individually cast patterns and $1.13 \mathrm{~mm}$ for the simultaneous casting of 3 patterns. This tendency was not observed in the sample of simultaneous casting of 4 patterns, which was once again observed for the casting of 5 patterns, with a mean empty gap of $1.45 \mathrm{~mm}$, or 6 patterns, with a mean of $2.44 \mathrm{~mm}$.
The aim of this study was to assess the influence of the number and location of resin patterns for casting of cast metallic posts (CMP) with a copper-aluminum alloy (CuAl) on the reproduction of the diameter and length of the posts.

\section{MATERIALAND METHODS}

Seventy-two patterns for posts were fabricated by utilization of prefabricated FKG plastic posts (Labordental), measuring $10 \mathrm{~mm}$ in length and $1 \mathrm{~mm}$ in diameter on its apical end. The coronal portion was obtained with Duralay resin (Reliance Dental Mfg. Co. Chicago, USA) and standardized by means of a template of addition silicone Express ${ }^{\mathrm{TM}}$ STD (3M ESPE, Dental Products, St. Paul, USA).

This template was rectangular in shape and measured $22 \mathrm{~mm}$ in width, $31 \mathrm{~mm}$ in length and $6 \mathrm{~mm}$ in depth, for positioning of the post. (Figure 1)

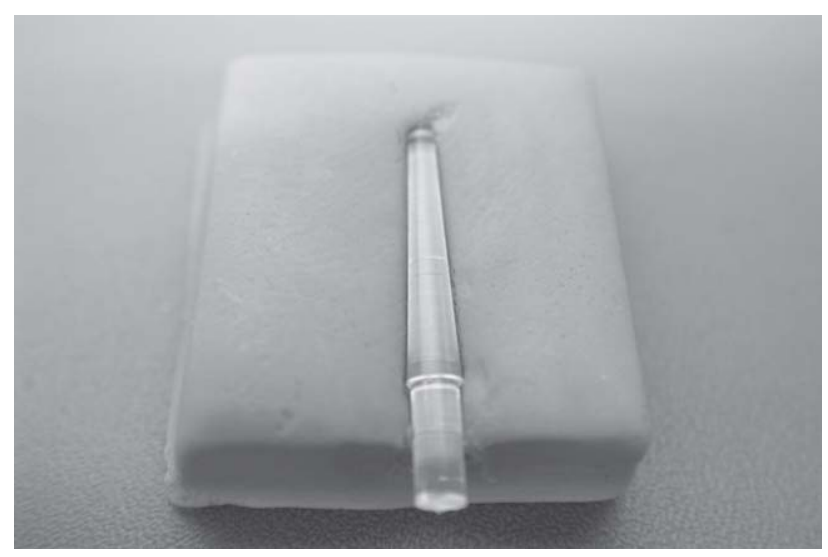

FIGURE 1- Radicular portion of template of addition silicone

Another template was achieved with the same material, which had a cavity to be filled with the Duralay resin for reproduction of the coronal portion of a CMP of a canine tooth. (Figure 2)

Both templates had grooves that allowed the same positioning of the coronal portion for all posts.

The patterns were divided into three groups according to the number of resin patterns:

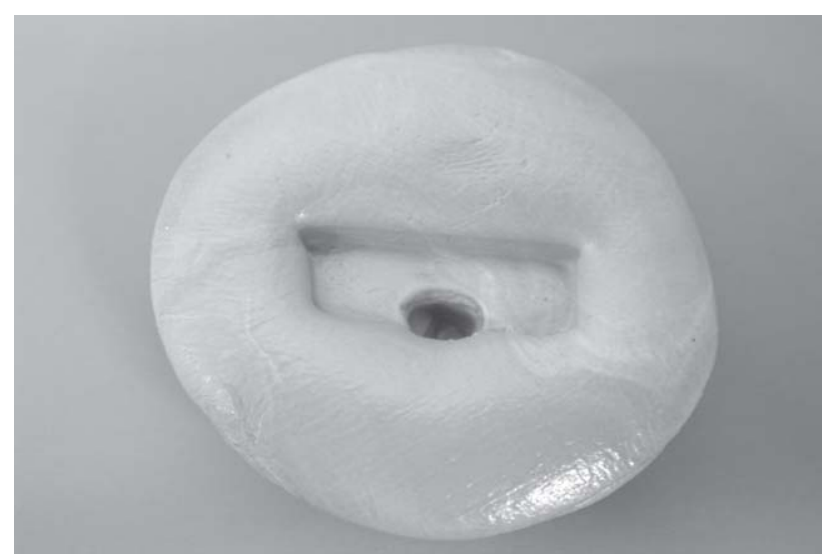

FIGURE 2- Coronal portion of template of addition silicone 
Group 1: 4 patterns invested in a small ring (3cm diameter) (Figure 3).

Group 2: 6 patterns invested in a medium ring $(4 \mathrm{~cm}$ diameter) (Figure 4).

Group 3: 8 patterns invested in a large ring ( $5 \mathrm{~cm}$ diameter) (Figure 5).

The patterns were positioned in a crossbeam-shaped sprue, so that half of the patterns were positioned at the right side of the ring midline and the other half at the left side, thus providing orientation for positioning of the ring

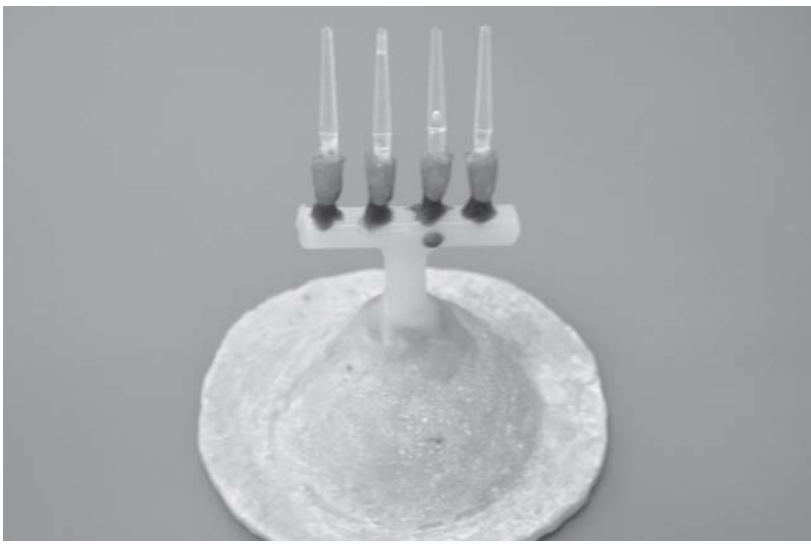

FIGURE 3- G1- 4 patterns/small ring

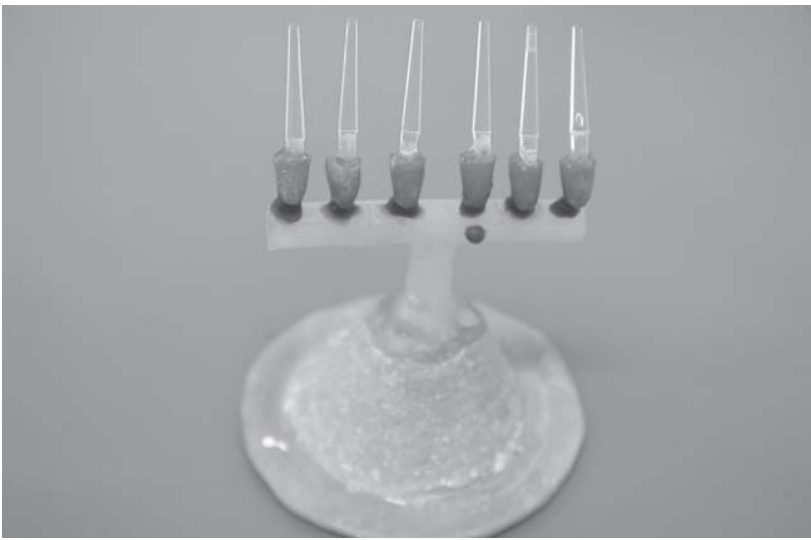

FIGURE 4- G2- 6 patterns/medium ring

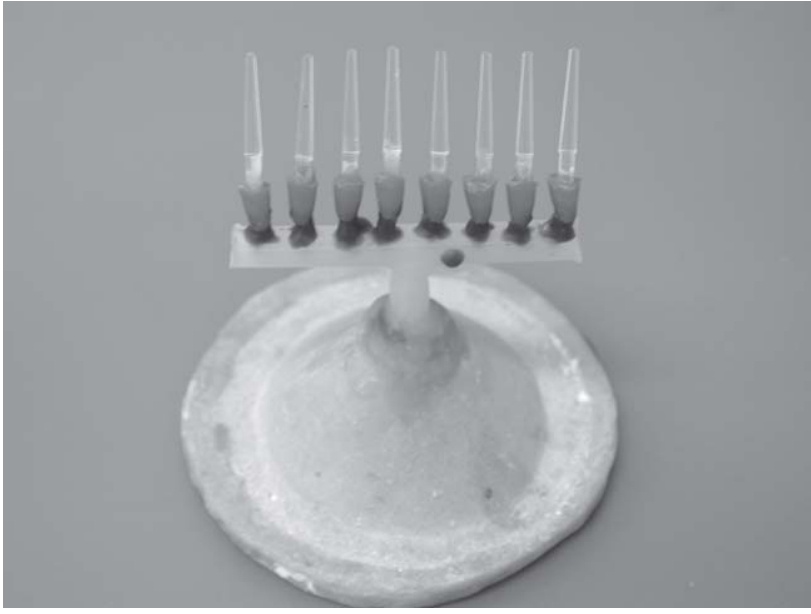

FIGURE 5- G3- 8 patterns/large ring in the centrifuge. This way, the patterns at the right were kept in the same direction of the rotation movement, whereas those positioned at the left of the ring were opposed to the movement.

Six castings were performed for Group 1, four for Group 2 and three for Group 3, adding up to 24 cast metallic posts for each group.

Investments were performed in metallic rings with the high-temperature investment Termocast (Polidental Ind e Comercio Ltda), vacuum-mixed following the manufacturer's instructions.

Casting of the copper-aluminum alloy (Goldent LA® AJE Comercio Imp. Exp. Ltda., Sao Paulo, SP, Brazil) was performed with a gas/air torch, and the molten alloy was injected inside the ring by means of a coil-driven centrifuge, with three turns.

The investments of the patterns and castings were conducted by a single laboratory technician.

Measurements were performed on a comparative microscope Mitutoyo (model 505, Japan) with 30x magnification before and after casting and comprised measurement of the post length from the salience present in prefabricated posts close to the coronal portion up to their end, and post diameter at the following points along its length: $3 \mathrm{~mm}, 6 \mathrm{~mm}, 9 \mathrm{~mm}, 10 \mathrm{~mm}$ and tip.

The results achieved were submitted to statistical analysis by the two-way ANOVA and the Tukey’s test, at a significance level of $5 \%$.

\section{RESULTS}

The mean results achieved ( $\mathrm{mm}$ ) and standard deviations for the three groups are displayed in Table 1.

The statistical analysis did not reveal statistically significant differences for all groups as regards the post length before and after casting according to the positioning of the patterns inside the casting ring (at the right or left sides of the ring midline).

Concerning the diameter, just measurements of the points 3, 6 and 9mm along the post length in Group G3 exhibited significant alterations.

\section{DISCUSSION}

Longevity of the prostheses is directly related to the proper fabrication of cast metallic posts, being the improper post length the main reason of failures of restorations performed in endodontically treated teeth.

In their study, Bonfante, et al. ${ }^{1}$ (2000) conducted a radiographic analysis of 1,000 posts and found that $80 \%$ had a shorter length than recommended by the $2 / 3$ rule and $70 \%$ according to the dental fulcrum rule, yielding forces distant from the fulcrum of these teeth, therefore increasing the possibility of fracture.

As regards the empty gap between the filling material and the post, the investigations of Rocha, et al. ${ }^{7}$ (1997) and 
Bonfante, et al. ${ }^{1}$ (2000) demonstrated its presence in $60 \%$ and $55.71 \%$ of the posts analyzed, respectively, demonstrating failures during the clinical and laboratory steps for fabrication of cast metallic posts. This failure was detected in relation to the number of patterns placed inside the ring during casting and was not observed during the achievement of posts with resin (Silva ${ }^{9}$ 1999).

Analysis of the results displayed in Table 1 reveals that the position of posts in the right or left side of the ring midline and the amount of patterns placed inside the ring (G1, G2 and G3) did not promote significant differences in the post length after casting, differently from the findings of Silva ${ }^{9}$ (1999), who observed a gradual shortening of the posts when cast with up to 3 patterns inside the ring, with mean values between the post length before and after casting of $0.17 \mathrm{~mm}$ ( 1 pattern) to $1.13 \mathrm{~mm}$ (3 patterns). This tendency was not observed in the sample of 4 patterns inside the ring, yet it was once again found with the placement of $5(1.45 \mathrm{~mm})$ or 6 patterns $(2.44 \mathrm{~mm})$. This leads to the occurrence of the empty gap between the post and the filling material, since the simultaneous casting of multiple patterns is a common procedure among laboratory technicians.

The same author assigns the failure in reproduction of the posts to the centrifuge force, being that the patterns positioned at the right side of the ring are more easily filled by the molten metal, since the centrifuge turns in counterclockwise direction, leading to flow of the alloy towards the opposed direction. On the other hand, the posts positioned at the left side of the ring midline will be opposed to the flow of the alloy and thus may be partially filled.

The investigations of Nilsen ${ }^{4}$ (1978), DeWald ${ }^{2}$ (1979) and Ogura, et al. ${ }^{5}$ (1981) demonstrated that the pathway of the flow of the molten metal inside the mold is influenced by the centrifuge, rotation and gravitational forces, being that the metal initially flows towards the side opposed to the rotation direction (right side of the ring). Thereafter, during deceleration of the centrifuge, the metal flows in a direction opposed to the rotation (left side of the ring), yet it solidifies first, due to the smaller supply of molten alloy associated to the cooling of the mold walls. Thus, the patterns placed at the left side of the ring may not be completely reproduced, especially when alloys of basic metals of low specific weight are employed.

In the present study, the clinically frequent observation of insufficient length of the cast metallic posts by means of radiographs was not reproduced by this methodology, since the patterns did not display a statistically significant reduction in length. This may be explained by the techniques of investment and casting employed, using a properly vacuum-mixed high-temperature investment and metallic rings, what leads to less expansion of the investment. The amount of alloy injected was correctly calculated by the technician, allowing a constant flow and generating heat inside the mold, therefore delaying cooling and solidification of the alloy.

Despite these observations, significant alterations were found in the diameter measurements for the posts in Group 3 for the points 3, 6 and 9mm, which may be explained by the non-uniform expansion of the investment, since the thickness of investment around each pattern is not homogeneous when several patterns are placed inside one ring. This variation in the post diameters before and after casting impairs the fitting of the posts during placement and may reduce or increase the space for the luting agent between the root canal walls and the post.

\section{CONCLUSION}

According to the methodology employed and considering the results analyzed and discussed, the following could be concluded:

- There were no significant alterations in relation to the side of the ring on which the patterns were located for all groups.

- There were no significant alterations in relation to length; however, significant alterations were observed for the diameters 3, 6, and 9mm in Group G3.

TABLE 1- Differences between measurements before and after casting

\begin{tabular}{lcccccc}
\hline & \multicolumn{3}{c}{ LEFT SIDE } & \multicolumn{3}{c}{ RIGHT SIDE } \\
& G1 & G2 & G3 & G1 & G2 & G3 \\
\hline Length & $0,21(0,14)$ & $0,23(0,14)$ & $0,07(0,17)$ & $0,21(0,10)$ & $0,42(0,87)$ & $0,12(0,15)$ \\
Diameter at 3mm & $0,00(0,03)$ & $0,02(0,03)$ & $0,00(0,01)$ & $0,01(0,02)$ & $0,02(0,03)$ & $0,00(0,01)$ \\
Diameter at 6mm & $0,02(0,02)$ & $0,02(0,02)$ & $0,00(0,01)$ & $0,01(0,01)$ & $0,02(0,02)$ & $0,00(0,01)$ \\
Diameter at 9mm & $0,03(0,02)$ & $0,02(0,02)$ & $0,01(0,01)$ & $0,02(0,01)$ & $0,03(0,02)$ & $0,01(0,01)$ \\
Diameter at 10mm & $0,02(0,03)$ & $0,05(0,15)$ & $0,01(0,02)$ & $0,02(0,02)$ & $0,02(0,02)$ & $0,00(0,06)$ \\
Diameter at tip & $0,02(0,03)$ & $0,04(0,07)$ & $0,01(0,19)$ & $0,02(0,07)$ & $0,02(0,02)$ & $0,06(0,12)$ \\
\hline
\end{tabular}




\section{REFERENCES}

1- Bonfante G, Fagnani CM, Miraglia SS, Silva Junior WS. Avaliação radiográfica de núcleos metálicos fundidos intrarradiculares. Rev Gaúcha Odontol 2000;48:170-4.

2- DeWald E. The relationship of pattern position to the flow of gold and casting completeness. J Prosthet Dent 1979;41:531-4.

3- Morgano SM, Milot P. Clinical success of cast metal post and cores. J Prosthet Dent 1993;70:11-6.

4- Nilsen JP. Pressure distribution in centrifugal dental casting. J Dent Res 1978;57:261-9.

5- Ogura H, Rapts NC, Asgar K. Inner surface roughness of complete cast crowns made by centrifugal casting machines. J Prosthet Dent 1981;45:529-35.

6- Phillips RW. Studies on the density of castings as related to their position in the

ring. J Am Dent Assoc 1947;35:329-42.

7- Rocha MPC, Nayoshido H, Siqueira AS. Avaliação do padrão de qualidade de núcleos metálicos fundidos em pacientes portadores de prótese fixa. Rev Paraense Odontol 1997;2:1-9.

8- Scaranelo RM, Bombonatti PE, Barros LE, Pellizzer AJ. Efeito das técnicas de fusão sobre a fluidez de ligas do sistema de cobrealumínio.Rev Odontol UNESP 1990; 19:211-6.

9- Silva CMF. Avaliação clínica e laboratorial de pinos fundidos em dentes unirradiculares. Bauru; 1999.[Monografia de Especialização Hospital de Reabilitação de Anomalias Craniofaciais, Universidade de São Paulo].

10- Sorensen J A., Martinoff, JT. Preservation of tooth structure. J Calif Dent Assoc 1988;16:15-22.

11- Valera MC, Cia D. Impermeabilização da obturação do canal radicular após praparo para o núcleo. Rev Gaúcha Odontol 2000;48:157-61.

12- Zuolo ML, Kato AS, Kherlakian D, Imura N. Microinfiltração coronária em dentes endodonticamente tratados após preparo do canal protético. Rev Assoc Paul Cirurg Dent 1996;50:253-7. 